\title{
Geodynamic Significance of Stacking Lower Cambrian Sequences Units in the Western Anti-Atlas
}

\section{Mohammed Benssaou, Lhassan M'barki, Abdelkrim Ezaidi, Mohamed Abioui}

Département de Géologie, Faculté des Sciences, Agadir, Maroc

\section{Email address:}

mbenssaou@yahoo.fr (M. Benssaou),mbarkilhassan@gmail.ac.ma (L. M’barki), a.ezaidi@uiz.ac.ma (A. Ezaidi), Abioui.gbs@gmail.com (M. Abioui)

\section{To cite this article:}

Mohammed Benssaou, Lhassan M' barki, Abdelkrim Ezaidi, Mohamed Abioui. Geodynamic Significance of Stacking Lower Cambrian Sequences Units in the Western Anti-atlas. International Journal of Materials Science and Applications Vol. 6, No. 3, 2017 , pp. $142-147$. doi: $10.11648 /$ j.ijmsa.20170603.15

Received: January 18, 2017; Accepted: March 8, 2017; Published: May 8, 2017

\begin{abstract}
In the Anti-Atlas the lower Cambrian succession was traditionally considered as a post-rift series. Recently the Western Anti-Atlas appears to be affected by an early Cambrian rifting process. In the Igherm area (Western Anti-Atlas), this succession is represented by an alternating carbonate and siliciclastic facies reflecting several sedimentary environments. The vertical stacking of these facies define four Composite-Sequences constituted, each one, by two or more transgressiveregressive sedimentary cycles. The differential and progressive extensional tectonic events seem to be the main control on the genesis and on the vertical stacking transgressive-regressive sedimentary cycles. The accommodation space is generated by a strong tilting related to syn-rift tectonics. The lack of lowstand system tracts and other erosive features, suggests the occurrence of platform drowning just below the falling sea level stage. So stratigraphic stacking of the Lower-Cambrian strata exposed in the Igherm area, constitutes the response to the rifting process in the Anti-Atlas and consequently a probably fragmentation indicator of a neoproterozoic Gondwana.
\end{abstract}

Keywords: Lower-Cambrian, Anti-Atlas, Composite Sequence, Tectonic

\section{Introduction}

In the Moroccan Anti-Atlas (fig. 1), the succession that was traditionally assigned to the Adoudounian-Lower Cambrian (Choubert, 1963), is recently attributed to a Lower Cambrian age [1]. In the Irherm area, the succession including, in ascending order, the Adoudou Formation, the "série lie de vin" Formation, the Igoudine Formation", the "Amouslek Formation and the "Issafene" Formation. This alternating carbonate and siliciclastic facies reflects two major carbonate transgressive deposits separated by a major glacio-eustatic regressive event represented by the siliciclastic "série lie de vin" Formation [2].

Through sedimentologic analysis and the recognition of sequence units by using sequence-stratigraphy concepts, we characterise the Lower Cambrian relative sea level change in the anti-atlasic margin of the Western African Craton. It is important to note that the principles of sequence stratigraphy have been, successfully, applied recently to analysis of Precambrian and Cambrian successions in spite of the stratigraphically fossils scarcity. We also address the potential impact of the Gondwana Lower Cambrian rifting on the genesis of vertical stacking sequence units that filled wide graben and half graben of the Souss basin. In the light of this it is interesting to note that the sedimentologic and stratigraphic patterns constitute the most sensitive indicators of syn-sedimentary tectonism in the absence of significant relic tectonic related structures.

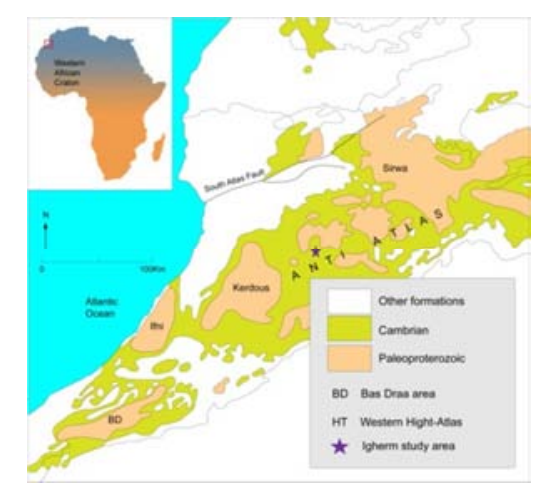

Figure 1. Geological sitting of the Igherm area in the western Anti-Atlas. 


\section{Stratigraphic Stacking of the Irherm Lower-Cambrian Succession}

The alternating sedimentary carbonates platform and reworked deltaic sediment within the Lower Cambrian succession in the Irherm area allows the distinction of four Composite Sequences similar to those defined by Mitchum et al. [3]. These sequences CS1, CS2, CS3 and CS4 (fig. 2A) are each one formed by two or more transgressivesregressives cycles (fig. 2B).

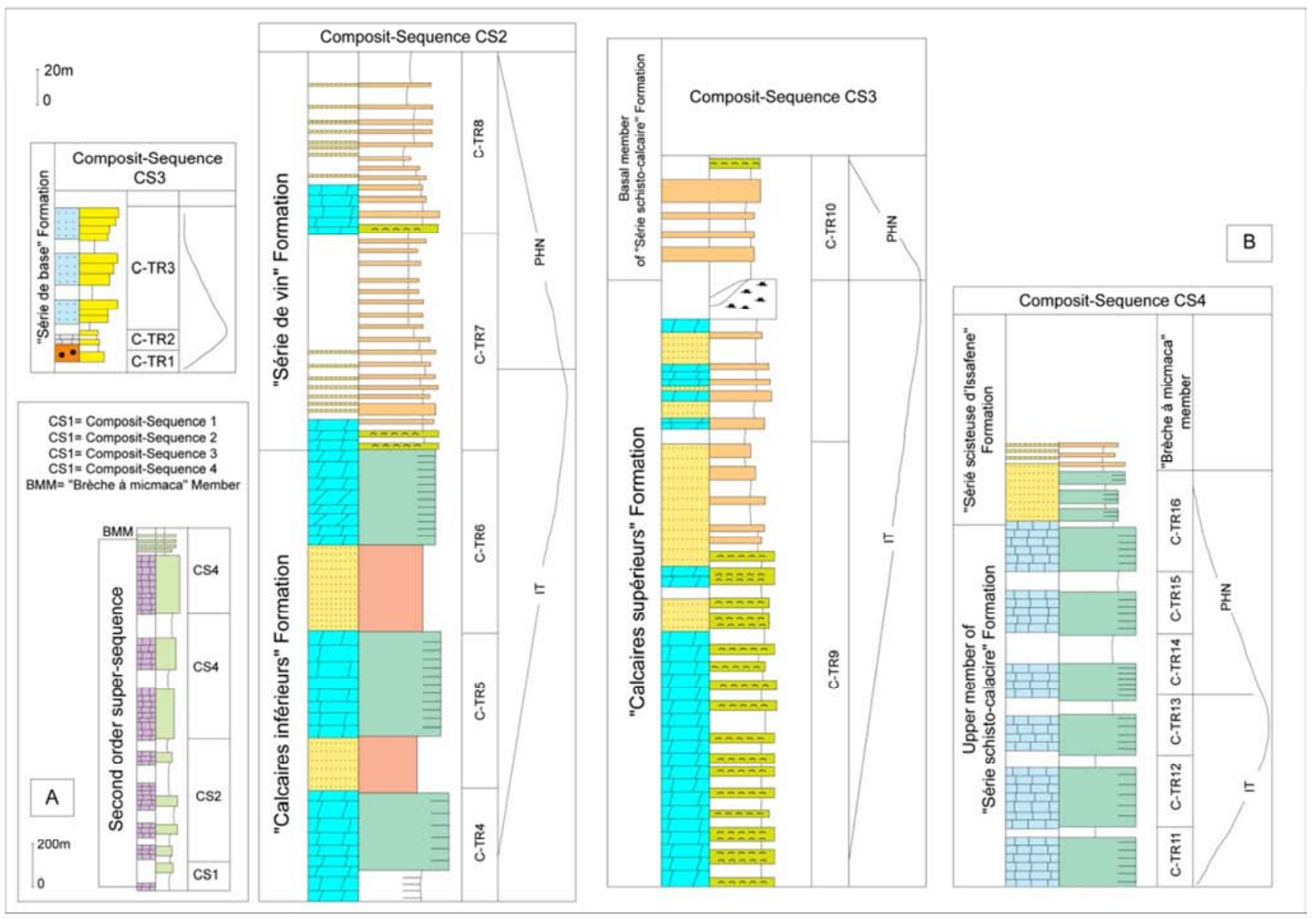

A - Composit-sequences of the igherm succession.

B - Transgressive-regressive cycles within composit-sequences.

Figure 2. Sequence stratigraphy of the succession developed in the Igherm.

\subsection{Composite Sequence One (CS1, Fig. 2)}

The basal contact of this composite sequence, marked by a conglomeratic infill of incised valley (S-TR i1), shows evidence for regional erosion and emplaces fluvial braid deposits over the Precambrian basement. This irregular contact corresponds to the type one boundary sequence of Van Vagoner et al. [4]. The uppermost deltaic facies (S-TR i3) of this composite sequence is overlain by a more distal marine carbonate facies (CS2). Because of this reversal of stacking order, the surface separating the CS1 and the CS2 is designated as a type two sequence boundary.

In the Irherm area (fig. 1), The CS1 include a basal conglomeratic member, a middle limestone member and an upper siltstone member of the "Madaw" Formation.

The facies association, that include a basal conglomeratic member, is interpreted as deposits of a fluvial system. The two main recognised fluvial facies are lenticular conglomerate anastomosing which was deposited within channel bars and medium-grained sandstone representing alluvial plain deposits. The fluvial facies association defins a fining up sequence (S-TR1) that reaches $10 \mathrm{~m}$ in thickness and can be interpreted as sub aerial infil of an incised valley during a start of sea level rise.

The limestone member consists of stromatolitic carbonates in amalgamated beds overlain by a metric interval of mixed facies that consists of centimetric thick stromatolitic carbonates strata separated by millimetric to centimetric argillaceous layers showing a dessiccation structures. The stromatolitic beds are morphologically domal form (type LLH of Logan et al, [5]). This cyanobacterial structures were formed by microbial trapping sediment in a tidal-flat environment [6]. The mixed facies corresponds, probably, to alluvial-plain deposits. The carbonate and siliciclastic facies association defines a transgressive-regressive cycle (S-TR2).

The siltstones member shows three facies associations in 
the Irherm area. The first one shows lenticular beds of massive micro-conglomeratic sandstone intercalated with dark grey argillaceous beds. This facies association represents a subtidal channel-fill deposits resulting from lateral accretion induced by tidal-currents. The second facies association includes typical tidal structures facies as flaserbedding, wavy-bedding and lenticular-bedding layers. This facies group, that shows strong hydrodynamic influence, may have developed in area similar to the modern North Sea intertidal-flats [7]. The third facies association is $60 \mathrm{~m}$ thick and mainly comprises reddish and grey sandy silt and fine grained sandstone. This facies, displaying a metric-scale cross lamination, the current ripples and ball and pillows structures, is organized in coarsening and thickening upward sequences that reflect a strong fluvial discharge in to a marine environment as deltaic mouth bar. This member, represented by the first and second facies associations results from reworking sediment in a shallow marine environment as a transgressive system tract and the third facies association shows evidence for deltaic-sediment progradation as a highstand system tract, constitutes a third transgressiveregressive cycle (C-TR3) of the $\mathrm{CS} 1$.

The CS1 composite sequence consists of basal conglomeratic member as a lowstand system tract, the basal limestone member and the two first facies association of the siltstone member as a transgressive system tract, and the third facies group of the siltstone member that constitutes the highstand system tarct. These characteristics indicate that the third order sea level change, to the origin of this composite sequence, includes the sea level rise stage followed by the highstand sea level stage. A sea level fall stage has not occurred as documented by a lack of erosional structures and a lack of the falling sea system tract (FSST).

\subsection{Composite Sequence Two (CS2, Fig. 2)}

The CS2 includes the Adoudou Formation and the "Série Lie de Vin" Formation. The upper surface of the CS2 is recognized by the presence of subtidal marine carbonates facies of the Igoudine Formation immediately above the uppermost progradational deltaic sequences of the "Série Lie de Vin" Formation and, subsequently, can be interpreted as a type two sequence boundary.

The microbial facies of the Adoudou Formation, includes planar cyanobacterial laminites and laterally linked hemispheroidal cyanobacterial laminites (type LLH of Logan [5]). The thickness could reach up $300 \mathrm{~m}$ in the Irherm region (fig. 2). The resulting vertical facies association shows a stack of three transgressive-regressive cycles (C-TR4, C-TR5 and C-TR6, fig. 2). Each of these shows a basal transgressive system tract and overlying by highstand system deposit. The transgressive system tract results from alternating stromatolitic carbonates with intertidal detritic one. This facies association defines repetitive metric scale regressive sequences. The highstand system tract is represented by thicknes of planar and domal stromatolitic carbonates that locally interlayered with silicified and evaporitic layers. Cyanobacterial carbonated rich evaporites facies were formed by trapping sediment in arid supratidal conditions, while siliceous layers indicate occasional moist conditions. Supratidal evaporites may have been dissolved during the occasional rains that occurred in the semi arid climate. This Alternating facies defined elementary metric sequences exhibiting stromatolitic rich evaporites as basal unit and bedforms or brechified silicified layers as sommital unit. Systematic changes in stacking facies in the meter scale sequences reflect alternating arid and moist climatic seasons and subsequently fluvially water discharge in supratidal depositional environment.

The "série lie de vin" Formation facies-associations contains an alternating microbial carbonates deposits and detrital siliciclastic deposits. The dominately thrombolitic facies result from laterally juxtaposed of individual thrombolitic build-up to form metric scale beds. Each thrombolitic build-up is domal to elliptic shaped and shows clotted or vacuolar internal fabric. Kennard and James [8] interpreted thrombolites as calcified microbial colonies surrounded by void-filling clastic sediment or calcitic cement. This formation comprises two transgressiveregressive cycles (C-TR7 and C-TR8). The basal member of each cycle forms a transgressive system tract, displaying thrombolitic facies in association with marley and argillaceous intercalated stromatolitics facies to form several shallowing upward metric sequences. These elementary sequences, generally composed of a basal subtidal thrombolitic facies overlain by lagoonal settling deposits, reflect a progressive shallowing and progradation as the rate of relative sea level rise decreased. The uppermost member, that constitutes the highstand system tract, show a stack of repetitive elementary sequences. Each sequence is formed by alternating decimetric stromatolitic beds and very thick (4 to $10 \mathrm{~m})$ waves reworked argillaceous and sandstones facies. These facies reflects episodic forced introduction of deltaic siliciclastic facies in a dominantly marine shallow-water carbonates.

The stratigraphic packing of the three cycles of the CS2 shows that this composit sequence start with a transgressive system tract that enclose the C-TR4, C-TR5, C-TR6 and the basal member of the C-TR7. It is followed by the uppermost member of the C-TR7 and C-TR8 as the Highstand system tract. This organization shows that the sea level rise stage is represented by an increasing water depth from a stromatolitic tidal-flats zone to subtidal thrombolitic environment, while the highstand sea-level stage is attested by a forced introduction of deltaic siliciclastic sediment in a depositional area.

\subsection{Composite Sequence Three (CS3, Fig. 2)}

The CS3 extends from the base of the "calcaires supérieurs" Formation to a middle part of the "série scistocalcaire" Formation. As in composit sequences CS1 and CS2, the surface separating storm reworked progradational deltaic at the top of the CS3 cycle and the dominated shelf carbonate facies of CS4 is a type two boundary sequence. The CS3 is constitutes by two transgressive-regressive cycles (C-TR9 
and C-TR10).

The transgressive system tract of the C-TR9 cycle shows a basal transgressive system tract similar to that describing in the C-TR7 and C-TR8 of the CS2, whiles the highstand system tract, is similar to that describing in the C-TR3 and CTR4 of the CS2.

The C-TR10 cycle is represented by three distinct facies associations. The lowermost one (60 m thick) consists of subtidal interbedded oolitic limestone and siliciclastic siltstones, the middle one consists of a $30 \mathrm{~m}$ thick of archecyathes and calcimicrobe bioherm buildup, and the uppermost one consists of repetitive elementary sequences formed by the massive or bioturbated mud tempestites at the base overlaying by amalgamated hummocky or massive sandstone. The two first facies associations vertical trend define a retrogradational pattern and could be interpreted as a transgressive system tract. The Highstand system tract of this cycle (C-TR10) is represented by the uppermost facies association. It consists of an upward-coarsening package of interbeded siltstones and mudstones grading upward into fine to medium sandstone. This facies association results from storm reworking deltas facies and reflects an important episode of forced introduction of siliciclastic sediments in a proximal marine platform.

The composit sequence CS3 is constituted by the C-TR9 and the lower member of the C-TR10, as a transgressive system tract, and the upper member of the C-TR10, as a highstand system tract. The basal transgressive system tract shows evidence for increasing water depth inducing distal shelf carbonates of the great atlasian reefal complex [9] and [10] over the subtidal oolithic platform, while the coarsening upward succession ( $40 \mathrm{~m}$ in thicknesse), that formed the highstand system tract, indicates a normal progradation under the highstand sea level stage as showing by the gradational contact between the HST facies. The tectonic increasing water depth lead also to the diversification of metazoan and bioturbation actyivity that caused the decline several microbial communities [11].

\subsection{Composite Sequence (CS4, Fig. 2)}

The CS4 extends from the middle part of the "série schisto-calcaire" Formation to the top of the "série schisteuse d'Issafene" Formation. The upper Boundary of this sequence, marked by a conglomeratic "brèche à micmaca" member over an erosional surface, can be compared to a type one boundary sequence. This Composit Sequence subdivided into six transgressive-regressive cycles (C-TR11 to C-TR16), contains several facies associations that define a metric scale elementary sequences that constitute an internal component of a basal transgressive system tract and a somital highstand system deposits within the recognised transgressivesregressives cycles.

The transgressive system-tract (TST) of these cycles, is almost formed by several shallowing upward elementary sequences showing evidence for shoaling from deep water to shallow water depht. Each sequence begins with a carbonate facies and finish by a foreshore silts and fine sandstones.
These carbonate facies correspond to: an upper shoreface oolitic limestone in the C-TR11 cycle, ii) a lower subtidal bioturbated oolitic and pisolitic limestones beds in the $\mathrm{C}$ TR12, C-TR14, C-TR15 and C-TR16 cycles and iii) a dominated distal shelf archeocyaths and calcimicrobes rrefal boundstone with minor subtidal oolitic and pisolitic limestone in the C-TR13 cycle.

The TST of the C-TR11 cycle is abruptly overlain by a 6 $\mathrm{m}$ thick of more proximal interbedded silts and sandstone that define an upward coarsening and thickening succession. This progradational pattern, is interpreted as a highstand system tract. In the C-TR14 cycle, the HST deposits is a $4 \mathrm{~m}$ thick of amalgamated sandstone beds exhibiting foreshore scolithos ichnofacies. In the C-TR12, C-TR13 and C-TR15 cycles, the Highstand system tract consists of 1 to $2 \mathrm{~m}$ thick mixed facies alternating with gray siliciclastic siltsones and sandstones displaying a foreshore structures. Above the TST of the C-TR16, there is a progradational $40 \mathrm{~m}$ thick succession expressed as a package of rock that coarsens up from shelf massive mudstone to fine and medium laminated or massive sandstone. This alternating facies defines three pro-deltaic coarsening up elementary sequences showing progradational evidence. The last of these is abruptly overlying by the "brèche à micmaca" member. This member consists of vertically stacked upward coarsening distal shelf sequences, generally of the order several meters. Each of these sequences shows a basal anomalously coarse grained and much fossiliferous conglomeratic facies overlaid by a distal shelf mud tempestites and proximal offshore sandstone beds.

The irregular upper boundary of the C-TR16 results from a sub-aerial platform erosion and reflects a forced regression that occurred during the sea level fall stage. The overlaying "brèche à micmaca" member is similar to that defined by Bondon and Neltner [12] in the central Anti-Atlas. The basal conglomeratic facies within this member is interpreted as a transgressive lag facies related to repetitive trransgressive events related to the early Middle-Cambrian high frequency sea level change. This changing sea level is, probably, controlled by the basin subsidence uplift related to the episodic epiorogenic movements recognised in the Anti-Atlas [13] and the High-Atlas [14]. This episodic basin basement uplift, inducing shoreface retreat, is seem to be occurred under the sea level rise conditions as documented by the lack of an evidence seaward shift facies. Under such tectonic and hydrodynamic context, the shallower water sediments that had, previously, been deposited in a distal marine shelf are eroded and the bioclastic sediment was deposited as a transgressive lag.

The composite Sequence CS4 is constituted by C-TR11, C-TR12 and C-TR13 as a transgressive system tract, and the C-TR14, C-TR15 and C-TR16 as the higstand system tract. This organization reflects an increasing sea level rise followed by a fall sea level stage. The sea level rise event begins with oolithic carbonates platform and shows evidence for increasing water depth inducinng distal shelf carbonates reefal build-up. The highstand sea level stage is represented 
by a foreshore and shoreface carbonate facies followed by deltaic sediments. The falling sea level stage is documented by erosion on the top of the "série shisteuse d'Issafene" and probably the erosion of the whole of the "Grès terminaux" Formation as signaled by Boudda and $a l$. [15]. The "brèche à micmaca" member represents, probably, the first onset stage of the lower Middle-Cambrian relative sea level rise.

\section{Interpretation of Stacking Sequence Units}

The Lower Cambrian succession, limited by two major unconformities and composed by four third order sea level change composit sequences, can be interpreted as a supersequence controlled by a second order sea level change. The composite sequences are formed by several transgressiveregressive cycles that show a basal transgressive system tract overlain by a highstand system tract. Each of these can be compared to the fourth order sea level change controlled large-scale simple sequence [16], while their component elementary sequences can be compared to the fifth order sea level change controlled small-scale simple sequences. The vertically transition in facies stacking from progradational to retrogradational patterns constitutes the main factor in the recognition of unconformity in outcrop within the transgressive-regressive cycles. These unconformities can be interpreted as a transgressive surfaces located, not at the top of the lowstand system tract as in transgressive-regressive sequences [17], [18] and [19], but at the top of the Highstand system tract as suggested by the lack of evidence of significant erosion and a falling sea level system tracts.

The Lower Cambrian composite sequences and their component transgressive-regressive cycles seem to be related to the differential tectonic regime that constitutes the main control on sedimentary processes during a phase of Early Cambrian rifting [20] started at the late Neoproterozoic-Early Cambian [21]; [22] and [23] and continued until the post Variscan time [24]. The extensional tectonic event induced a rising sea level wich forms a transgressive system tract, while the progradation in a relative tectonic quiescence stage allows the formation of the highstand system tract. The occurrence of tectonic subsidence event just bellow the falling sea level stage, as documented by the lack of lowstand system deposit and other erosive features, almost caused platform drowning. The lack of falling stage features and subsequently erosional unconformities suggest that the highstand system deposit occurred principally in a normal regressive conditions. This suggested tectonic control on vertical stacking sequences is documented by authors [25], [26] and [27] to explain the third and fourth order sea level fluctuations in particular basins as rifts, foreland and extensional intracratonic basins. The combined extensive tectonic event with a long term sea level rise, as suggested by [28] for the Cambrian time, is the main factor on building vertical stacking transgressive-regressive sequences in the Anti-atlas.

\section{Conclusion}

The Lower-Cambrian outcrops at Igherm display four composits sequences that stacked vertically to form one second order sea level change controlled super sequence. Each composite-sequence is formed by two or more transgressive and regressive cycles and represents four episodes of the African craton anti-atlasic margin development. The fist composite-sequence CS1 is dominated by fluvial and deltaic sediment with minor carbonates deposits representing the first post pan-african orogeny marine incursion. A significant thinly CS1 thickness expresses a probable slowly subsiding Igherm paleo-edge. The second composite-sequence CS2 represents a prolonged period in which greater areas of the platform were occupied by supratidal to subtidal sediments relayed by an episodic forced introduction of siliciclastic facies in a dominantly marine subtidal carbonates. During the latest composite sequences CS3 and CS4 deposits, the introduction of two argillaceous episodes in the carbonate platform is assured by repetitive progradation of siliciclastic belts as deltas that formed the farther basin borders.

The Lower-Cambrian composite sequences and their component transgressive-regressive cycles seem to be related to the differential tectonism that constituts the main control on sedimentary processes during Lower Cambrian rifting. We suggest that the recognised sequence units, in the Igherm area, are driven by a long term eustatic rise, strongly modified by episodic extensional tectonic subsidence related to the Lower-Cambrian fragmentation of the Gondwana super-continent.

\section{References}

[1] Geyer, G et Landing, E (1995). The Cambrian of the Moroccan Atlas regions. In Morocco' 95, the Lower-Middle Cambrian standard of Western Gondwana, Beringeria special issue 2, Wurzburg, 7-46.

[2] Choubert, G (1963). Histoire géologique du Précambrien de l'Anti-Atlas. Notes et Mém Serv Géol du Maroc, 162, 352 p.

[3] Mitchum R M, John C and Van Wagoner (1991). Highfrequency sequences and their stacking patterns: sequencestratigraphic evidence of high-frequency eustatic cycles. Sedimentary Geology, 70, pp. 131-160.

[4] Van Wagoner J. C, Mitchum R. M., Campion K. M. and Rahmanian, V. D. (1990). Siliciclastic sequence stratigraphy in well logs, cores and outcrops: concepts for hight resolution correlation of time and facies. American Association of petrolieum geologists, Methods in exploration series. $7,55 \mathrm{p}$.

[5] Logan, B. W., Hoffman, P. et Gebellin, C. D. (1974). Algal mats, cryptagal fabrics and structures, hamelin pool, western Australia. The americain assoc. of petro. Geol. Memoire, $\mathrm{n}^{\circ}$ 22,141-194.

[6] Glumac, B. et Walker, R. G. (1997). Selective dolomitization of cambrian microbial carbonate deposits: a key to mechanisms and environments of origin. Palaios, volume 12.2, 98-110. 
[7] Aigner, T. et Reineck, H. E. (1982). Proximality trends in modern storm sands from the Helgoland Bight (North sea) and their implications for basin analysis. - Sencken Bergiana Maritina, 14, p. 183-185.

[8] Kennard, J. M. and James, N. P. (1986). Thrombolits and stromatolits: Two distinct types of microbial structures. Palaios, $1,492-503$

[9] Benssaou et Hamoumi (2004). Les microbialites de l'Anti-Atlas occidental (Maroc): marqueurs stratigraphiques et témoins des changements environnementaux au Cambrien inférieur. C. R. Géosciences 336:109-116.

[10] Javier Alvaro J., Debrenne, F., (2010): The geat Reef complex: An early Cambrian subtropical fringing belt that bordered West Gondwana. Palaeogeography, Palaecology, 204, 120-132.

[11] Claussen S., Javier Alvaro J., Zamora S., (2014): Replacement of benthic communities in Low Neoprterozoic-Cambrian subtropical - to - temperate rift basins High Atlas and AntiAtlas, Morocco, Journal of African Earth Sciences 98, 72-93.

[12] Bondon, J. et Neltner, R. L. (1933). Sur la série cambrienne des plateaux du Draa (Sud marocain) et la présence de Géorgien dans cette série. C. R. Acad. Sci. Paris, t. 197, 170.

[13] Hupé P., (1955) - Indices d'une phase tectonique salaïrienne dans l'Anti-Atlas marocain. C. R. Acad. Sci. Paris, 241, 244246.

[14] Ouanaimi, H. (1988) - Evolution sédimentaire et tectonique de la partie orientale du massif ancien du Haut-Atlas (Maroc). Thèse, Univ. Montpelier-II, 402p.

[15] Bouda, A., Choubert, G. et Faure-Muret, A. (1979). Essai de stratigraphie de la couverture sédimentaire de l'Anti-Atlas: Adoudounien-Cambrien inférieur. Notes et Mem. Serv. Géol. Maroc, $\mathrm{n}^{\circ} 271,95 \mathrm{p}$.

[16] McNaughton R., Dalrymple R. W., and Narbornne G. M. (1997). Multiple orders of sea-level change in an earliest Cambrian passive-margin succession, Mackenzie Mountains, Northwestern Canada. Journal of Sedimentary Research, vol. $67, \mathrm{n}^{\circ} 4$, pp. 622-637.

[17] Embry A. F. et Johansen E. P. (1992). T-R sequence stratigraphy, facies analysis and reservoir distribution in the uppermost Triasic-Lower Jurassic succession, western Sverdrup Basin, Arctic Canada in: Vorren T. O., Bergsager, E., DahlStamnes, Q. A, Holter E. Johansen, B., Lend T. B. (Eds), ArcticGeology and Petrolum potential. Norwegian Petrolum Society Spec. Publ.2, Elseiver, Amsterdam, pp. 121-146.

[18] Embry, A. F. (1993). Transgressive-regressive (T-R) sequence analysis of the Jurassic succession of the Sverdrup Basin, Canadian Arctic Archipelago. Can. J. Earth Sci. 30, 301-320.

[19] Embry A. F. (1995). Sequence boundaries and sequence hierarchies: problems and proposals. In: Steel, R. J., Felt, V. L., Johansen E. P., Mathieu, C. (eds), Sequence Stratigraphy on the Northwest Eurpean Margin. Norwegian Petroleum Society Spec. Publ. 5, Elseiver, Amsterdam, pp. 1-11.
[20] Catuneanu O, Willis A. J, et Miall A. D. (1998). Temporal significance of sequences boundaries. Sedimentary Geology, 121, pp. 157-178.

[21] Catuneanu O, Abreu V, Battacharaya J. P, Blum M. D, Dalrymple, R. W, Erikson, P. G., Fielding, C. R., Fisher W. L, Galloway, J. E, Jordan R., Kendall G. G. ST. C., Maanda B, Martinsen O. J, Miall A. D., Neal J. E, Nummedal D, Pumar L, Posamentier, H. W., Pratt B. R, Sarg J. F., Shanely K. W., Steel R. J., Strasser A, Tucker, M. E., Wink C. (2009): Towards the standarizing of sequence stratigraphy, Earth-Science Revieus, 92, 1-33.

[22] Benssaou et Hamoumi (1999). L'Anti-Atlas occidental du Maroc: remplissage sédimentaire d'un bassin d'un bassin de type rift au Cambrien inférieur. Revue Géologie Méditerranéenne, tome XXVI, n 3-4, pp. 259-279.

[23] [21] Benssaou et Hamoumi (2003). Le Graben de l'Anti-Atlas occidental (Maroc): Contrôle tectonique de la paléogéographie et des séquences au Cambrien inférieur. C. R. Géosciences 335: 297-305. Doi 10.1016/S 1631-0713(03) 00033-6.

[24] Burkhart M., Cartig S., Helg U. et al. (2006): Tectonics of the Anti-Atlas of Morocco. C. R. Géosciences, 338, 11-24, doi: 10. 1016Lj crte 2005.11.012.

[25] A Soulaimani, A Michard, H Ouanaimi, L Baidder, Y Raddi, O Saddiqi, EC Rjimati (2014): - Late Ediacaran-Cambrian structures and their reactivation during the Variscan and Alpine cycles in the Anti-Atlas (Morocco), Journal of African Earth Sciences 98, 94-112.

[26] Gouiza M., Charton R., Bertotti G., Andreissen P., and Storms J. E., (2016): Post variscan evolution of Anti Atlas belt of morocco constrained from low-temperature geochronology. Int. J. Earth Sci. (Geol Rundsh), DI 1007/s 00531-016-1325-0.

[27] Cloetingh S. (1986). Intraplate stresses: A new mechanism for fluctuations of relative sea level. Geology, V. 14, p. 617-620.

[28] Cloetingh S. (1988). Intraplate stresse: A tectonic cause for third-order cycles in apparent sea level. In Wilgus, C. K., et al., (eds): Sea Level Changes - An Integrated Approch, SEPM, Special Publication 42, p. 26-28.

[29] Miall A. D. (1991). Stratiphic sequences and their chronostratigraphic correlation. Journal of Sedimentary Petrology, vol. 61, $\mathrm{N}^{\circ}$ 4, pp. 497-505.

[30] Ito M., Nishikawa T. et Sugimoto H. (1999). Tectonic controlof high- frequency depositional sequences with durations shorterthan Milankovitch cyclicity: An example from the Pleistocene paleo-Tokyo Bay, Japan. Geology, v. 27, $\mathrm{n}^{\circ}$ 8, p. 763-766.

[31] Fisher A. G. (1982). Long-term climatic osscillations recordedin stratigraphy. In: Climatic in earth history. Studies in Geophysics, Nat. Academey Press, Washington DC, p. 97-104. 